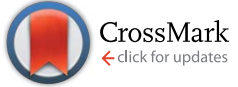

Cite this: RSC Adv., 2015, 5, 74734
Received 29th July 2015

Accepted 28th August 2015

DOI: $10.1039 / \mathrm{c} 5 \mathrm{ra15071j}$

www.rsc.org/advances

\section{Polyhydroxylated GdDTPA-derivatives as high relaxivity magnetic resonance imaging contrast agents $\uparrow$}

\author{
Lorenzo Tei, ${ }^{\text {*a }}$ Alessandro Barge, ${ }^{\mathrm{b}}$ Matteo Galli, ${ }^{\mathrm{c}}$ Roberta Pinalli, ${ }^{\mathrm{c}}$ Luciano Lattuada ${ }^{\text {} c}$ \\ Eliana Gianolio ${ }^{d}$ and Silvio Aime ${ }^{d}$
}

\section{Introduction}

The use of Gd(III)-chelates as contrast enhancing agents (CA) for Magnetic Resonance Imaging (MRI) has developed considerable research activity aimed at the design of effective, specific and safe CAs. ${ }^{1}$ The efficacy of a contrast agent is expressed by its relaxivity, $r_{1}$, which is the enhancement of the longitudinal proton relaxation rate induced by the paramagnetic agent at $1 \mathrm{mM}$ concentration. Theory predicts high relaxivity for a $\mathrm{Gd}(\mathrm{III})$ complex when the rate of water exchange between the inner sphere and the bulk solvent $\left(k_{\mathrm{ex}}=1 / \tau_{\mathrm{M}}\right)$ is around $10^{6}-10^{7} \mathrm{~s}^{-1}$ and when the molecular reorientational time and electron spin relaxation time are similar and long at the selected field strength. ${ }^{1,2}$ Nowadays, clinical MR imaging is increasingly moving to higher fields since the number of installed 3 Tesla scanners is steadily growing worldwide. ${ }^{3}$ Higher fields improve the signal-to-noise ratio (SNR) and provide higher spatial resolution and/or reduced acquisition times. ${ }^{4}$ Considering this trend, there is the need of contrast agents endowed with a high

\footnotetext{
${ }^{a}$ Dipartimento di Scienze e Innovazione Tecnologica, Università del Piemonte Orientale “Amedeo Avogadro", Viale T. Michel 11, 15121 Alessandria, Italy.E-mail: lorenzo.tei@ uniupo.it

${ }^{b}$ Dipartimento di Scienza e Tecnologia del Farmaco, Università di Torino, via P. Giuria 9, 10125 Torino, Italy

${ }^{\circ}$ Bracco Imaging SpA, Bracco Research Centre, via Ribes 5, 10010 Colleretto Giacosa, TO, Italy.E-mail: luciano.lattuada@bracco.com

${ }^{d}$ Department of Molecular Biotechnology and Health Sciences, Molecular Imaging Center, Università di Torino, Via Nizza 52, 10126, Torino, Italy

$\dagger$ Electronic supplementary information (ESI) available: ${ }^{1} \mathrm{H}$ and ${ }^{13} \mathrm{C}$ NMR spectra of novel compounds. See DOI: 10.1039/c5ra15071j
}

relaxivity over an extended range of magnetic field strength. ${ }^{5}$ High-relaxivity CAs permit the use of lower doses in routine clinical applications and are the candidates of choice in molecular imaging procedures aimed at detecting lowconcentration targets. Optimizing the three contributions that determine the observed relaxation rates of water protons, namely inner-, second- and outer-coordination sphere, could lead to highly efficient CAs.

One route followed in the search for higher relaxivities relied on the lengthening of the molecular reorientational time through the formation of polymers or of covalent and noncovalent conjugates between the paramagnetic chelate and slowly moving substrates ${ }^{6}$ (dendrimers, ${ }^{7}$ proteins,${ }^{8}$ carbohydrates $^{9}$ ) and the formation of supramolecular adducts like micelles or liposomes. ${ }^{10}$ In most cases, these systems display maximum $r_{1}$ values at $20-40 \mathrm{MHz}$ (i.e. $0.5-1 \mathrm{~T}$ ) but their relaxation enhancement ability decreases quickly at higher fields. Therefore, medium size molecular weight Gd-based compounds have been proposed in order to obtain good relaxivity values over the 0.5-3 T magnetic field range. Examples of these systems are based either on oligomeric (2-8 units) Gd(III) complexes ${ }^{4,11}$ or on monomeric Gd-complexes with the $\mathrm{Gd}^{3+}$ ion at the baricentre of the macromolecule with a well-structured second sphere of hydration. ${ }^{12}$ Similar symmetric structures based on DOTA (DOTA $=1,4,7,10$-tetraazacyclododecane1,4,7,10-tetraacetic acid) but with higher molecular weights (5-7 kDa) were reported to have a relaxivity drop at magnetic fields higher than $1 \mathrm{~T}(40 \mathrm{MHz}){ }^{13}$ Moreover, their dimensions allow only a slow diffusion in the extravascular space. 
Due to their pharmacokinetic profile, the diagnostic applications of this type of contrast agents are different not only from the already marketed non-specific agents that freely and quickly distribute into the extracellular space, but also from blood pool agents that mainly distribute into the blood system. In light of these considerations, there still is the need for improved nonspecific contrast agents able to combine high relaxivity with rapid extravasation, as required for angiographic- and perfusion-based diagnostic applications.

We have faced this problem by synthesizing new Gd(III) complexes based on the structure of DTPA functionalized with highly hydrophilic substituents in order to remarkably increase the second sphere contribution to the relaxivity by creating a structured network of water molecules localised around the polyhydroxyl groups. Ligands $\mathbf{L 1}$ and $\mathbf{L} 2$ are DTPA-bisamides bearing two differently branched gluconyl moieties and L3 is based on a DTPA derivative in which the central arm has been replaced by a methyl phosphonate moiety (P-DTPA) and two outer acetate moieties bear each the triply gluconyl substituted polyol. The choice of a P-DTPA derivative relies on the published observation that its Gd(III) complex shows an optimal value of $\tau_{\mathrm{M}}$ (about $\left.88 \mathrm{~ns}\right) \cdot{ }^{14}$ Moreover, phosphonate moieties have been shown to yield good second sphere contributions to the observed relaxivity due to hydrogen bonded water molecules localised between the phosphonate group and the Gd. ${ }^{15}$ In the present work, we report on the synthesis of L1-L3 ligands and on a ${ }^{1} \mathrm{H}$ and ${ }^{17} \mathrm{O}$ NMR relaxometric study on the corresponding Gd(III) complexes.

\section{Results and discussion}

\section{Ligands design}

The introduction of polyhydroxylic or glycosylic groups at the periphery of a Gd(III) complex has been considered previously with different purposes. In some reports, CAs structures that

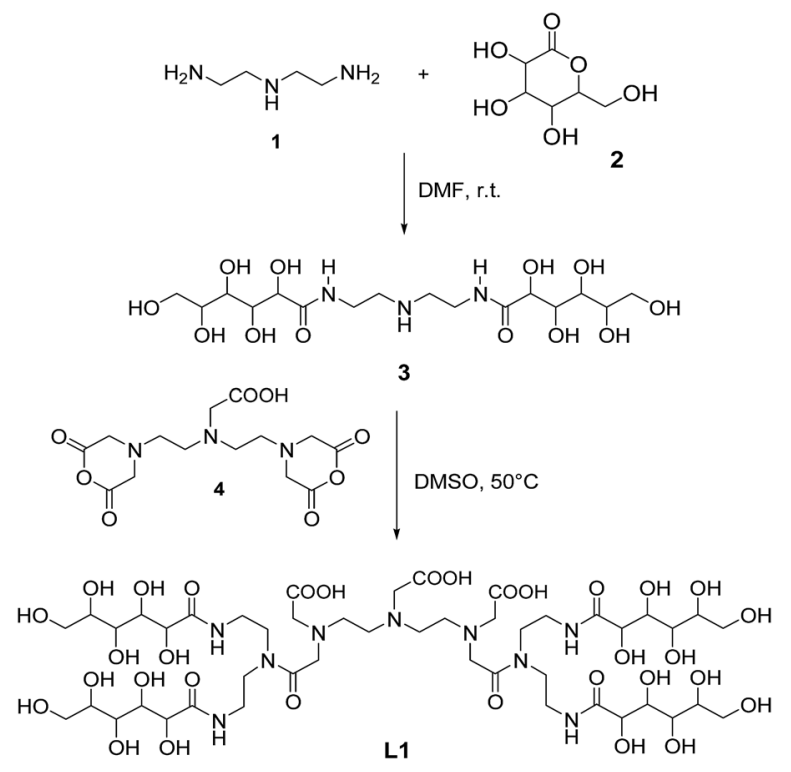

Scheme 1 Synthesis of the DTPA-bisamide L1. incorporate glucose and galactose/mannose moieties were developed with the intent to enhance targeting in vivo. ${ }^{16}$ Others groups engineered complexes in which the Gd(III) ion lied at the barycentre of the macromolecular structure surrounded by a well-defined second hydration sphere to obtain higher relaxivities. $^{12,13}$ Furthermore, a water-solubilizing polyhydroxylic dendron was incorporated to improve the poor water solubility of the parent complex. ${ }^{17}$ Our work started with the synthesis of two diamides of DTPA (L1 and L2) bearing differently branched polygluconyl groups on the outer surface. The assessment of the relaxometric properties of their Gd-complexes allowed us to determine the best hydrophilic pendant group for the attainment of a large second sphere contribution to relaxivity. Two examples of DTPA-bisamides bearing two acetylglucose units and a dendrimeric glycosidic cluster with six acetylgluconamides at the periphery were already reported with the aim to create new blood pool CAs more than to evaluate the effect of the second sphere water molecules surrounding the Gd(III) centre. ${ }^{18}$ As we were aware that DTPA-bisamides are characterized by a very slow water exchange rate $\left(k_{\mathrm{ex}}\right)$ that "quenches" any putative inner sphere relaxivity gain, our next task dealt with the introduction of two polyhydroxy-containing moieties on P-DTPA ligand.

Bifunctional derivatives of DTPA have been reported either with the remote functional group on the central acetate arm or on the diethylenetriamine backbone. ${ }^{19}$ Only one example of
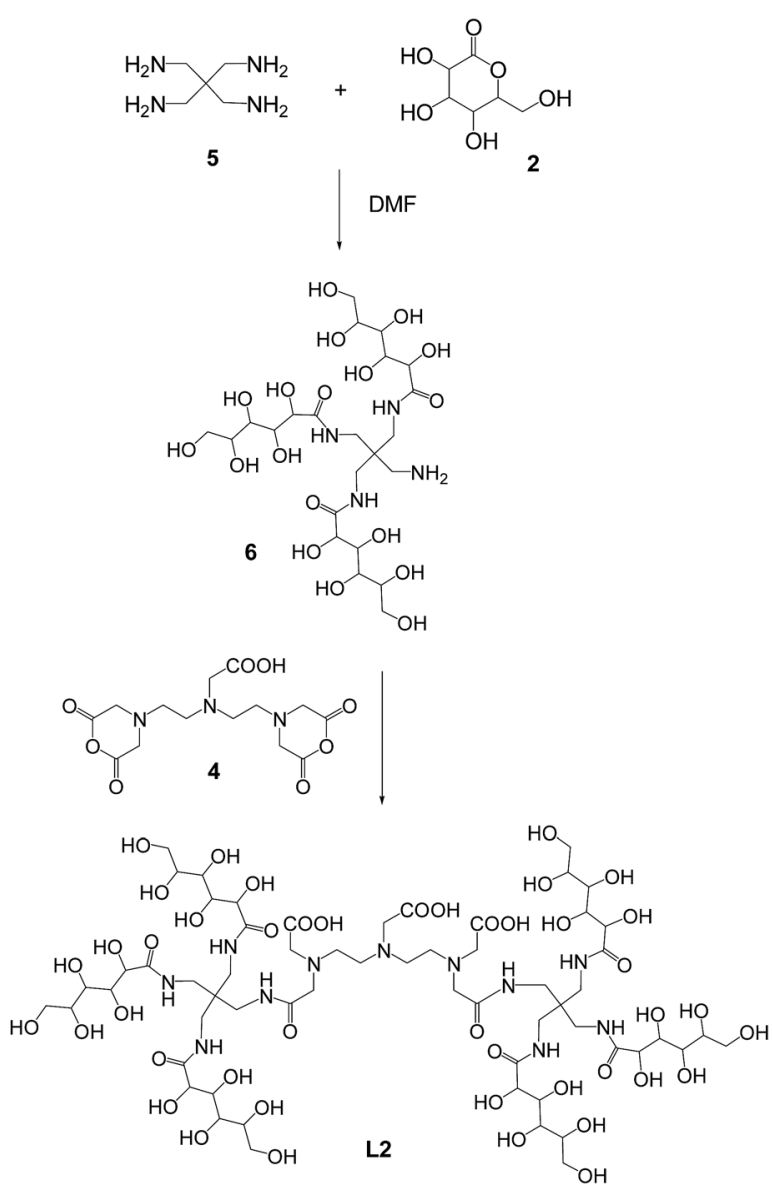

Scheme 2 Synthesis of the DTPA-bisamide L2. 


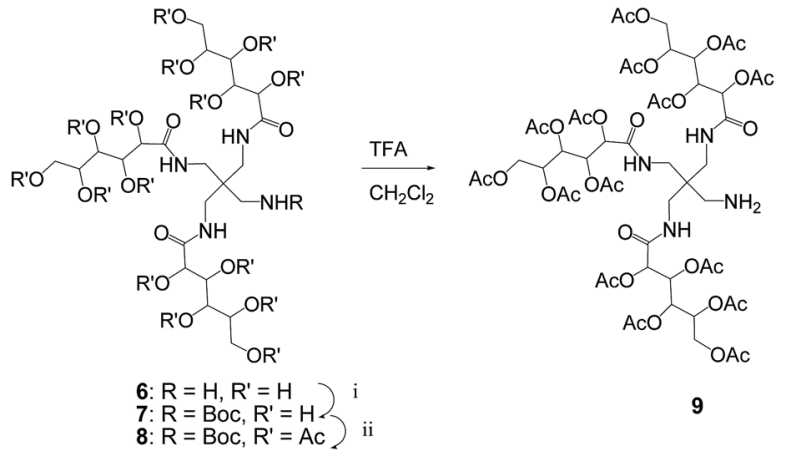

Scheme 3 Synthesis of the fully acetylated aminopolyol 9; (i) $\mathrm{Boc}_{2} \mathrm{O}$, $\mathrm{TMAOH}, \mathrm{DMF}, 48 \mathrm{~h}$; (ii) $\mathrm{Ac}_{2} \mathrm{O}, \mathrm{Py}, 90^{\circ} \mathrm{C}, 24 \mathrm{~h}$.

functionalization of a lateral acetate pendant arm was described $^{20}$ and to the best of our knowledge a bisfunctionalized DTPA-like agent has never been reported. Thus, the bifunctional chelating ligand 15 (Scheme 4) was designed having four carboxylic and the phosphonic groups tert-butyl protected and two free carboxylic groups able to react with amino functionalized moieties. Then, the ligand L3 could be prepared by reacting the bifunctional agent 15 with two dendronized polygluconyl groups with the aim to increase the amount of hydroxyl groups and to create a symmetric Gd(III) complex with lateral hydrophilic moieties and a central phosphonate group.

\section{Synthesis}

The polyol functionalised DTPA bisamide L1 (Scheme 1) was synthesized in one step with an overall 61\% yield starting from DTPA bis-anhydride $\mathbf{4}^{21}$ and $N, N^{\prime}$-(iminodi-2,1-ethanediyl)bis-Dgluconamide 3 , previously obtained by amidation of diethylenetriamine 1 with $\delta$-gluconolactone 2 (Scheme 1). Similarly, the DTPA bisamide $\mathbf{L} 2$ was synthesised by reaction of DTPA bisanhydride 4 with the tris-gluconoyl amide derivative 6 obtained by reaction between pentaerythrityl tetramine $5^{22}$ and $\delta$-gluconolactone (Scheme 2). Aiming to use this amino-functionalised polyol for further syntheses, we decided to prepare the fully acetylated derivative 9 (Scheme 3 ). Thus, the amino group of $\mathbf{6}$ was protected with (Boc) $)_{2} \mathrm{O}$ and tetramethylammonium hydroxide in DMF to give 7. Then, all the hydroxyl groups were acetylated with $\mathrm{Ac}_{2} \mathrm{O}$ in pyridine to give $\mathbf{8}$ and, finally, 9 was obtained by removing the Boc protection with TFA in $\mathrm{CH}_{2} \mathrm{Cl}_{2}$.

The synthetic procedure to obtain $\mathbf{L} 3$, depicted in Scheme 4, relies on the strategy published by Williams and Rapoport who reported the $N$-bisalkylation of $p$-nitrophenylalanine benzyl ester with different bromoethylamines as a direct method for the construction of protected DTPA analogues. ${ }^{23}$ Moreover, following this procedure, modified amino acids have been bisalkylated with [ $N$-(bromoethyl)amino]diacetic acid $t$-butyl ester in order to obtain functionalized DTPA pentaesters as versatile intermediates for the preparation of conjugates of metal complexes. ${ }^{\mathbf{1 9 2 4}}$ We exploited this idea in a different way by synthesising a bromoethyl derivative of protected aspartic acid and reacting it with an aminomethyl phosphonate. By this route, after orthogonal deprotection of two carboxy benzylester groups, we were able to attach an amino-polyol molecule on both sides of the P-DTPA derivative. In particular, L-aspartic acid 4-benzyl ester 10 was esterified, using $t$-butyl acetate in the presence of catalytic perchloric acid, into L-aspartic acid 1-tertbutyl 4-benzyl diester 11, which was directly reacted with one equivalent of $t$-butyl bromoacetate under Rapoport's two-phase conditions (i.e.: $\mathrm{MeCN} / \mathrm{pH} 8$ phosphate buffer) to yield, after chromatographic purification, the mono-alkylated compound 12 in $76.5 \%$ yield. Triester 12 was then further alkylated with 2-bromoethyl-trifluoromethansulfonate in order to obtain in good yield the bromoethyl component $\mathbf{1 3}$ to be used for the construction of the P-DTPA derivative (Scheme 4).

The other component was the aminomethylphosphonic acid di-tert-butyl ester 19 (Scheme 5) obtained in two steps by Mannich reaction of dibenzylamine with paraformaldehyde and tertbutyl phosphite, followed by hydrogenolysis of the benzyl group at atmospheric pressure with $10 \% \mathrm{Pd} / \mathrm{C}$ catalyst. The Rapoport's conditions were also used for the alkylation of 19 with two equivalents of $\mathbf{1 3}$ (no excess was used) to get the P-DTPA derivative 14 in $42.4 \%$ yield after column purification. Cleavage of the benzyl ester protections of $\mathbf{1 4}$ by hydrogenolysis yielded the diacid pentaester 15. This compound was then coupled to the amino-protected polyol 9 in DMF at room temperature for $48 \mathrm{~h}$ by using HATU (O-(7-azabenzotriazol-1-yl)- $N, N, N^{\prime}, N^{\prime}$-tetramethyluroniumhexafluoro phosphate) as coupling reagent and

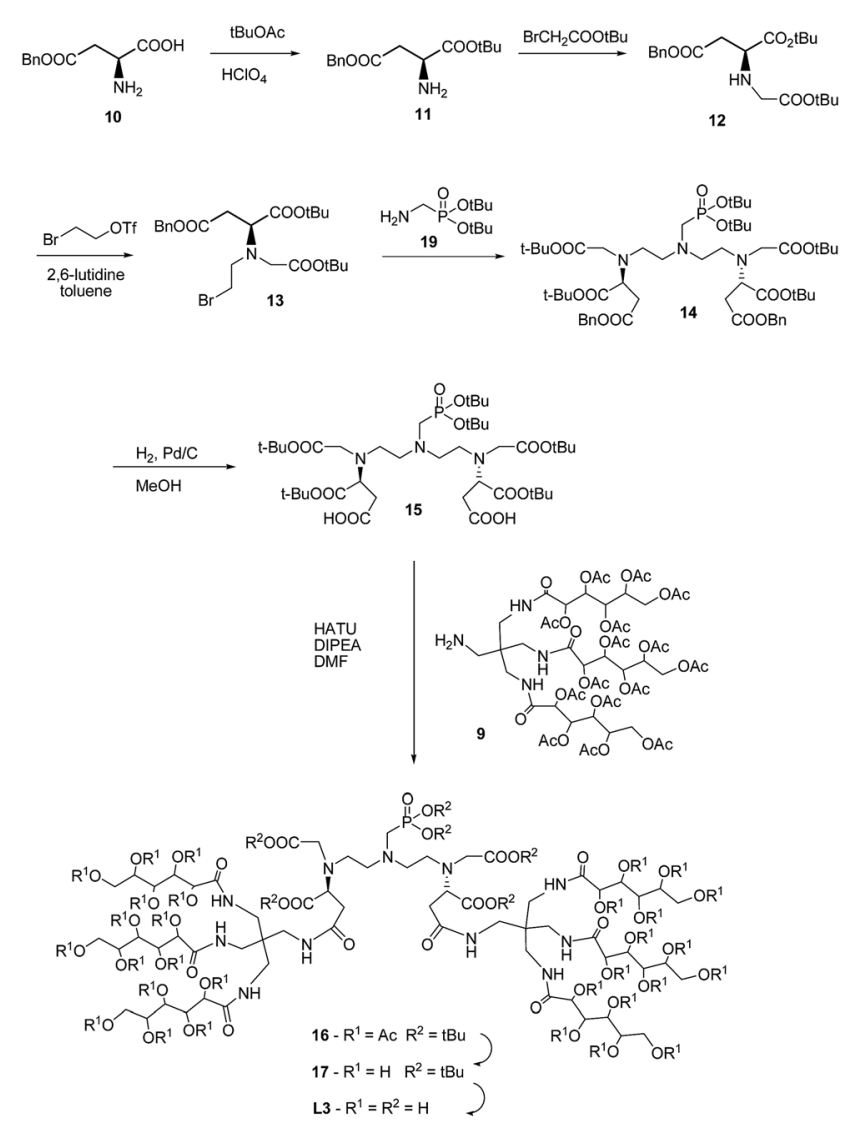

Scheme 4 Synthesis of L3. 


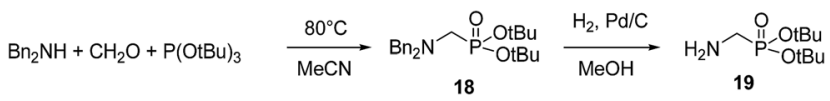

Scheme 5 Synthesis of aminomethylphosphonic acid di-tert-butyl ester 19.

$\mathrm{N}, \mathrm{N}$-diisopropyl ethylamine as base. Product 16, together with a small amount of the mono-substituted derivative, was collected by precipitation in cold water. Due to difficulties met during the purification procedures, it was decided to use this mixture without separating the mono-functionalized impurity. Deacetylation of the polyalcohol was afforded by bubbling ammonia in a refrigerated methanol solution of $\mathbf{1 6}$. This reaction was completed only after 9 days and after bubbling more ammonia every two days. In order to obtain the final ligand L3, the last step was the cleavage of the $t$-butyl esters by reaction with a $50 \%$ solution of trifluoroacetic acid in $\mathrm{CH}_{2} \mathrm{Cl}_{2}$ and precipitation by addition of diethyl ether. In order to get pure $\mathbf{L 3}$ a simple procedure was followed: the trifluoroacetate salt obtained after $t$ butyl ester deprotection was redissolved in water, brought to $\mathrm{pH}$ 7, lyophilized and recovered with methanol. Ligand L3 was thus obtained as a white solid in $30 \%$ yield by filtration of the $\mathrm{MeOH}$ solution. On the other hand, evaporation of the solvent give rise to an oil which resulted to be the mono-polyol derivative present in about $28 \%$ of the total raw material.

\section{Relaxivity of the Gd(III) complexes}

The Gd(III) complexes GdL1, GdL2 and GdL3 were prepared by ${ }^{1} \mathrm{H}$ NMR relaxometric titration with a stock solution of $\mathrm{GdCl}_{3}$ at pH 6.5 monitoring the change in the longitudinal water proton relaxation rate $\left(R_{1}\right)$ at $20 \mathrm{MHz}$ and $298 \mathrm{~K}$ as a function of the concentration of $\mathrm{Gd}^{3+}$. The slope of the straight line obtained corresponds to the relaxivity $\left(r_{1}\right)$ of the complex. The residual

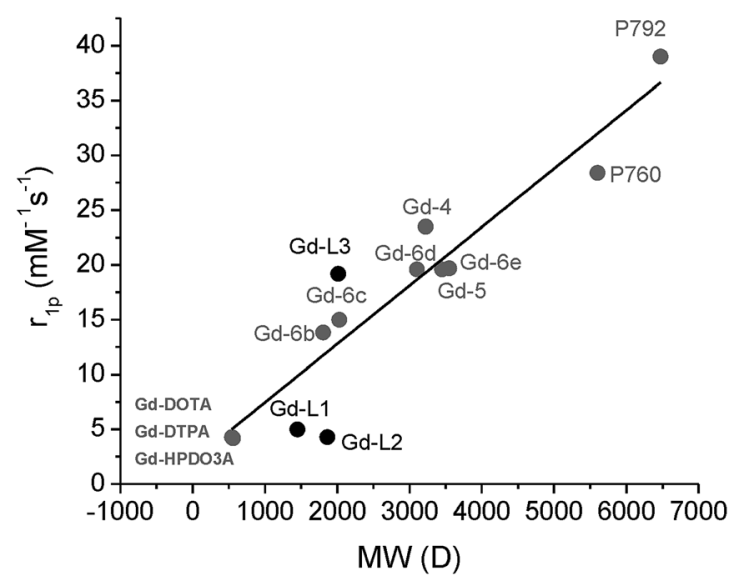

Fig. 1 Relaxivities $\left(r_{1}\right)$ values, measured at $298 \mathrm{~K}$ and $20 \mathrm{MHz}$, of GdL1, GdL2 and GdL3 as a function of their molecular weight compared to those reported for other $q=1$ complexes. Values for Gd-DOTA, Gd-DTPA and Gd-HPDO3A come from ref. 2, for Gd-4 and Gd-5 from ref. $12 a$, for $G d-6 b, 6 c, 6 d$ and 6 e from ref. $12 b$ and for P760 and P792 from ref. 13 free $\mathrm{Gd}^{3+}$ ion was quantified by Orange Xylenol UV method as lower than $0.2 \%$ in all complexes. ${ }^{25}$ The exact concentration of $\mathrm{Gd}^{3+}$ ions was determined by measurement of the bulk magnetic-susceptibility shifts of the $t \mathrm{BuOH}$ signal. The relaxivity $\left(r_{1}\right)$ values at $20 \mathrm{MHz}$ and $298 \mathrm{~K}$ are $5.0 \mathrm{mM}^{-1} \mathrm{~s}^{-1}$ for GdL1, $4.3 \mathrm{mM}^{-1} \mathrm{~s}^{-1}$ for GdL2 and $19.2 \mathrm{mM}^{-1} \mathrm{~s}^{-1}$ for GdL3. In Fig. 1, the relaxivities of the three Gd-chelates are plotted as a function of their molecular weight and compared to those reported in the literature for monomeric Gd-complexes with one coordinated water molecule at $T=298 \mathrm{~K}$ and $B_{0}=0.5 \mathrm{~T}$. While the $r_{1}$ values for the two GdDTPA-bisamides GdL1 and GdL2 are significantly lower than the values expected on the basis of their molecular weight, the $r_{1}$ of the Gd(III) complex with the monophosphonic DTPA derivative L3, is markedly higher than expected for a molecule of such molecular weight. Noteworthy, the relaxivity of GdL3 is more than four times higher than that of the parent $\operatorname{GdDTPA}\left(r_{1}=4.7 \mathrm{mM}^{-1} \mathrm{~s}^{-1}\right)$. A more detailed relaxometric characterization was carried out through the registration of the ${ }^{17} \mathrm{O}$ NMR- $R_{2 p}$ profiles as a function of temperature (for an accurate determination of the exchange lifetime $\left(\tau_{\mathbf{M}}\right)$ of the coordinated water molecule - Fig. 2) and of the ${ }^{1} \mathrm{H}-\mathrm{NMRD}$ profiles over the range of frequencies from 0.01 to $120 \mathrm{MHz}$ (Fig. 3A and B).

The analysis of the ${ }^{17} \mathrm{O}$ NMR experimental data yielded the $\tau_{\mathbf{M}}$ values reported in Table 1 . The value found for GdL3 (93 ns) is very similar to that already reported for related GdP-DTPA derivatives $^{\mathbf{1 4}}$ and very close to the optimal value for the achievement of high relaxivity. ${ }^{\mathbf{1 , 2}}$ On the contrary, very long $\tau_{\mathbf{M}}$ values ( $5.6 \mu \mathrm{s}$ and $7.6 \mu \mathrm{s}$, for GdL1 and GdL2 respectively) were found for the two bisamides derivatives. This slow water exchange rate, which is invariably found in GdDTPA-bisamides, ${ }^{26}$ is responsible for the low relaxivity shown by GdL1 and GdL2. The proton relaxivity data measured as a function of the magnetic field strength at $298 \mathrm{~K}$ and neutral pH (Fig. 3A and B) were well interpolated with the set of values calculated on the basis of the classical Solomon-Bloembergen-Morgan theory by fixing the $\tau_{\mathrm{M}}$ values to those obtained by ${ }^{17} \mathrm{O} \mathrm{NMR}-R_{2 \mathrm{p}}$ analysis. The main parameters obtained from the fitting of experimental to calculated data are reported in Table 1. As expected, a

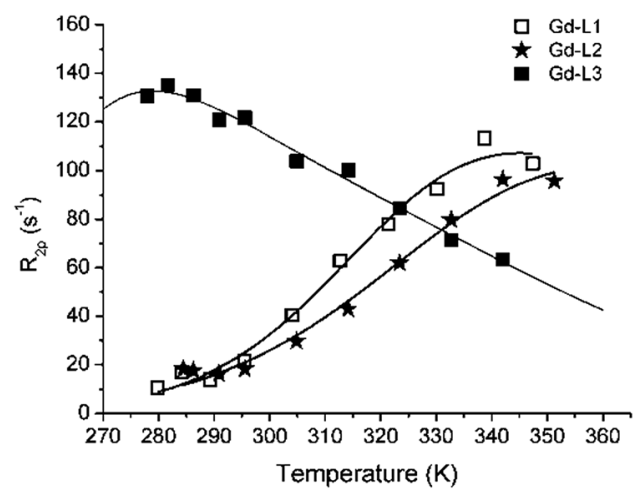

Fig. 2 Temperature dependence of the paramagnetic contribution to the ${ }^{17} \mathrm{O}$ transverse relaxation rate of water for GdL1, GdL2 and GdL3 $(10 \mathrm{mM})$ measured at $2.1 \mathrm{~T}$ and $\mathrm{pH} 7$. 

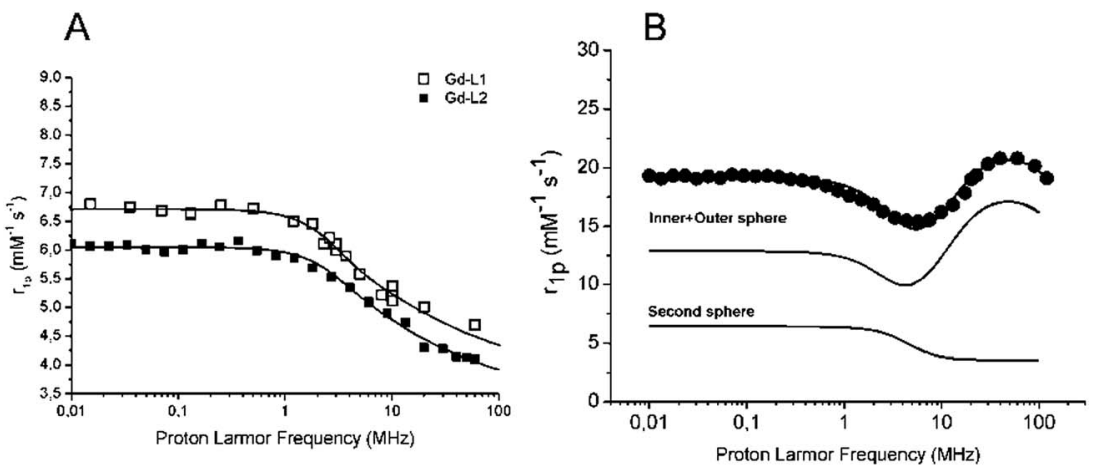

Fig. $31 / T_{1}$ NMRD profiles of GdL1, GdL2 (A) and GdL3 (B) recorded at $298 \mathrm{~K}$ and pH 7. The data refer to a $1 \mathrm{mM}$ concentration of the paramagnetic complexes. The solid curves through the data points were calculated with the parameters reported in Table 1 , whereas the dotted lines in (B) refer to the different contributions to the overall relaxivity.

Table 1 Best-fit parameters obtained from ${ }^{1} \mathrm{H}-\mathrm{NMRD}$ at $298 \mathrm{~K}$ and ${ }^{17} \mathrm{O}-R_{2 \mathrm{p}}$ versus $\mathrm{T}$ analysis shown in Fig. 2 and $3^{a}$

\begin{tabular}{llllllll}
\hline & $\Delta^{2}\left(\times 10^{19} \mathrm{~s}^{-2}\right)$ & $\tau_{\mathrm{V}}(\mathrm{ps})$ & $\tau_{\mathrm{R}}(\mathrm{ps})$ & $\tau_{\mathrm{M}}(\mu \mathrm{s})$ & $q$ & $q^{\mathrm{ss}}$ & $r^{\mathrm{ss}}(\AA)$ \\
\hline Gd-L1 & $2.9 \pm 0.57$ & $22.1 \pm 1.8$ & $305 \pm 12.8$ & $5.6 \pm 1.2$ & 1 & 0 & - \\
Gd-L2 & $2.1 \pm 0.57$ & $25.0 \pm 1.5$ & $470 \pm 68.1$ & $7.6 \pm 0.6$ & 1 & 0 & - \\
Gd-L3 & $2.2 \pm 0.13$ & $34.2 \pm 0.10$ & $560 \pm 10.8$ & $0.093 \pm 0.003$ & 1 & $3.5 \pm 0.4$ & 3.7
\end{tabular}

${ }^{a}$ On carrying out the fitting procedure, some parameters were fixed to reasonable values: $r_{\mathrm{Gd}-\mathrm{H}}$ (distance between Gd and protons of the innersphere water molecule) $=3.1 \AA$; $a$ (distance of minimum approach of solvent water molecules to Gd ion) $=4 \AA$; $D$ (solvent diffusion coefficient) $=2.24 \times$ $10^{-5} \mathrm{~cm}^{2} \mathrm{~s}^{-1} \cdot r^{\mathrm{Ss}}$ (distance between Gd and protons of the second sphere water molecules) $=3.7 \AA$. . [ $\Delta^{2}$ ] Squared mean transient zero-field splitting (ZFS) energy. $\left[\tau_{\mathrm{V}}\right]$ Correlation time for the collision-related modulation of the ZFS Hamiltonian. $\left[\tau_{\mathrm{R}}\right]$ Reorientational correlation time. $\left[\tau_{\mathrm{M}}\right]$ Exchange lifetime of the coordinated water molecule. [q] Number of inner-sphere water molecules. $\left[q^{\mathrm{ss}}\right]$ Number of second-sphere water molecules. $\left[\tau^{\mathrm{ss}}\right]$ correlation time associated with the motions (reorientation or exchange) of the second-sphere water molecules.

progressive increase in the reorientational correlation time $\left(\tau_{\mathrm{R}}\right)$ occurs upon increasing the molecular weight.

In the case of GdL3 (Fig. 3B), a good fitting of the experimental data was possible only by taking into account a contribution from second sphere water molecules. ${ }^{27} 3.5$ second sphere water molecules $\left(q^{\mathrm{ss}}\right)$ were estimated to be located at an average distance of $3.7 \AA$ from the $\mathrm{Gd}^{3+}$ ion with an overall correlation time $\left(\tau^{\mathrm{ss}}\right)$ of $93 \mathrm{ps}$ (Table 1$)$. The increase in the correlation time associated with the collision-related modulation of the zero-field splitting Hamiltonian $\left(\tau_{\mathrm{V}}\right)$ observed in the case of GdL2 and GdL3, is likely related to the occurrence of a reduced rate of solvent collisions between the coordinated and bulk water molecules. Tentatively, one may relate the observed behavior to the enhanced shielding of the poly-hydroxylic containing moieties with respect to GdL1.

In summary, one may conclude that the high relaxivity shown by GdL3 is the result of the occurrence of three positive conditions: (i) an array of second sphere water molecules linked through hydrogen bond to the phosphonate moiety, (ii) a fast water exchange rate of the coordinated water molecule and (iii) the increased molecular weight $\left(\tau_{\mathrm{R}}=560 \mathrm{~ns}\right)$ determined by the introduction of the poly-hydroxylic substituents on the surface of the metal complex. Noteworthy, the relaxivity values for GdL3, measured at the Larmor frequencies more used on clinical scanners $(40,60,120 \mathrm{MHz}$ corresponding to 1, 1.5 and $3 \mathrm{~T}$, respectively), are somehow constant, being $20.8 \mathrm{mM}^{-1} \mathrm{~s}^{-1}$ at 40 and $60 \mathrm{MHz}$ and $19.1 \mathrm{mM}^{-1} \mathrm{~s}^{-1}$ at $120 \mathrm{MHz}$.

\section{Experimental}

\section{General}

All reagents and solvents were obtained from commercial suppliers and directly used without further purification. $N, N^{\prime}$-Bis[2-(2,6-dioxo-4-morpholinyl)ethyl]glycine (DTPA-bis-anhydride) $\mathbf{4},{ }^{21}$ pentaerythrityl tetramine tetrahydrochloride $\mathbf{5},{ }^{22}$ tert-butyl phosphite $^{28}$ and 2-bromoethyl trifluoromethanesulfonate ${ }^{29}$ were synthesized as reported in literature. TLC was performed on Merck silica gel 60 TLC plates F254 and visualized by using UV (254 nm) or $1 \% \mathrm{KMnO}_{4}$ in $1 \mathrm{~N} \mathrm{NaOH}$. Column chromatography was performed by using silica gel 60 (70-230 mesh) while flash chromatography was carried out on silica gel 60 (230-400 mesh). The ${ }^{1} \mathrm{H},{ }^{13} \mathrm{C}$ and ${ }^{31} \mathrm{P}$ spectra were recorded on a Bruker Avance 400 instrument. Chemical shifts are reported in $\delta$ relative to an internal standard of residual chloroform $\left(\delta 7.27\right.$ for ${ }^{1} \mathrm{H}$ NMR and 77.16 for ${ }^{13} \mathrm{C}$ NMR). ESI MS spectra on novel compounds were acquired on a high resolving power mass spectrometer LTQ Orbitrap (Thermo Scientific, Rodano, Italy), equipped with an atmospheric pressure interface and an ESI ion source. Other mass spectra were recorded with a ThermoFinnigan TSQ700 triple-quadrupole instrument equipped with an electrospray ionization source. Analytical HPLC was performed on a Merck KGaA apparatus with the following method: stationary phase: Lichrospher RP-Select B $5 \mu \mathrm{m}, 250 \times 4 \mathrm{~mm}$ column packed by Merck KGaA; mobile phase: eluent $A=0.01 \mathrm{M} \mathrm{KH}_{2} \mathrm{PO}_{4}$ and $0.017 \mathrm{M} \mathrm{H}_{3} \mathrm{PO}_{4}$ in $\mathrm{H}_{2} \mathrm{O}$, eluent $\mathrm{B}=\mathrm{MeCN}$, gradient elution: $t=$ 
$0 \min (5 \% \mathrm{~B}), t=30 \min (80 \% \mathrm{~B}) ; T=45{ }^{\circ} \mathrm{C}$; flow rate: 1 $\mathrm{mL} \min ^{-1}$; UV detection: $210 \mathrm{~nm}$.

Synthesis of $\boldsymbol{N}, \boldsymbol{N}^{\prime}$-(iminodi-2,1-ethanediyl)bis-D-gluconamide (3). Diethylenetriamine 1 ( $1 \mathrm{~g}, 9.7 \mathrm{mmol})$ was added dropwise to a suspension of $\delta$-gluconolactone 2 (3.6 g, $20.3 \mathrm{mmol}$ ) in DMF $(10 \mathrm{~mL})$. The reaction mixture was stirred at room temperature for $1.5 \mathrm{~h}$. The precipitate was filtered, washed with $\mathrm{CH}_{2} \mathrm{Cl}_{2}$ $(500 \mathrm{~mL})$, to remove DMF and the excess of $\delta$-gluconolactone, and dried to obtain 3 as a white solid (4.06 g, $8.83 \mathrm{mmol}$ ), yield 91\%; mp $142{ }^{\circ} \mathrm{C}$ (dec.); $R_{\mathrm{f}} 0.12$ (eluent $\mathrm{CHCl}_{3} / \mathrm{MeOH} / 25 \%$ $\left.\mathrm{NH}_{4} \mathrm{OH} 30: 60: 20\right) ;{ }^{1} \mathrm{H}$ NMR $\left(600 \mathrm{MHz}, \mathrm{D}_{2} \mathrm{O}\right) \delta 4.24(\mathrm{~d}, J=$ $5.0 \mathrm{~Hz}, 2 \mathrm{H}), 4.00(\mathrm{~d}, J=5.0 \mathrm{~Hz}, 2 \mathrm{H}), 3.72(\mathrm{~d}, J=16.9 \mathrm{~Hz}, 2 \mathrm{H})$, $3.66(\mathrm{~m}, 4 \mathrm{H}), 3.55(\mathrm{dd}, J=11.0,4.4 \mathrm{~Hz}, 3 \mathrm{H}), 3.31(\mathrm{dt}, J=12.1$, $9.2 \mathrm{~Hz}, 4 \mathrm{H}), 2.71(\mathrm{t}, J=9.2 \mathrm{~Hz}, 4 \mathrm{H}) ;{ }^{13} \mathrm{C} \mathrm{NMR}\left(151 \mathrm{MHz}, \mathrm{D}_{2} \mathrm{O}\right) \delta$ 175.08 (CO), 73.81 (C-2), 72.50 (C-3), 71.45 (C-4), 70.70 (C-5), $62.96(\mathrm{C}-6), 47.33\left(\mathrm{CH}_{2} \mathrm{~N}\right), 38.45\left(\mathrm{CH}_{2} \mathrm{~N}\right)$.

Synthesis of $N, N$-bis [2-[(carboxymethyl)[2-[bis[2-[(D-gluconoyl) amino]ethyl] amino]-2-oxoethyl] amino] ethyl]glycine (L1). $N, N^{\prime}$ Bis-[2-(2,6-dioxo-4-morpholinyl)ethyl]glycine (DTPA-bis-anhydride $)^{21} 4$ (0.19 g; $\left.0.54 \mathrm{mmol}\right)$ was added to a solution of 3 ( $0.5 \mathrm{~g}$; $1.09 \mathrm{mmol})$ in DMSO $(5 \mathrm{~mL})$ and the yellow solution was stirred at $50{ }^{\circ} \mathrm{C}$ for $8 \mathrm{~h}$. After cooling at room temperature, the reaction mixture was diluted with $\mathrm{CH}_{2} \mathrm{Cl}_{2}(50 \mathrm{~mL})$; the precipitate was filtered, washed with $\mathrm{CH}_{2} \mathrm{Cl}_{2}(200 \mathrm{~mL})$ then lyophilized to remove the residual DMSO. L1 was obtained as white solid (0.42 g; $0.33 \mathrm{mmol}$ ), yield $61 \%$; mp $128-130{ }^{\circ} \mathrm{C} R_{\mathrm{f}} 0.30$ (eluent $\mathrm{MeOH} /$ 25\% $\mathrm{NH}_{4} \mathrm{OH} 7$ : 3); HPLC: retention time $2.1 \mathrm{~min}$, 98\% (area\%); ${ }^{1} \mathrm{H}$ NMR $\left(600 \mathrm{MHz}, \mathrm{D}_{2} \mathrm{O}, 333 \mathrm{~K}\right) \delta 4.70-4.58(\mathrm{~m}, 10 \mathrm{H}), 4.37(\mathrm{~s}, 4 \mathrm{H})$, $4.18(\mathrm{~s}, 4 \mathrm{H}), 4.12-4.05(\mathrm{~m}, 12 \mathrm{H}), 3.98-3.85(\mathrm{~m}, 12 \mathrm{H}), 3.78(\mathrm{~m}$, 12H), $3.49(\mathrm{~m}, 4 \mathrm{H}) ;{ }^{13} \mathrm{C}$ NMR (151 MHz, $\left.\mathrm{D}_{2} \mathrm{O}, 333 \mathrm{~K}\right) \delta 175.68$, 175.36, 174.90, 171.11, 167.40 (CO), 74.21 (C-2), 74.15 (C-2'), 73.97 (C-3), 73.07 (C-3'), 72.72 (C-4), $72.19\left(\mathrm{C}-4^{\prime}\right), 71.30$ (C-5), 62.56 (C-6), 58.16, 56.80, $56.02\left(\mathrm{CH}_{2} \mathrm{CO}\right), 53.92,50.42\left(\mathrm{CH}_{2} \mathrm{~N}\right), 47.41,46.55$ $\left(\mathrm{CH}_{2} \mathrm{~N}\right), 37.49,36.50\left(\mathrm{CH}_{2} \mathrm{NH}\right)$. ESI-HRMS $(\mathrm{m} / \mathrm{z}): 1276.4563$ $\left(\mathrm{M}+\mathrm{H}^{+}\right)$(calcd 1276.5379).

Synthesis of $N$-[[2,2-bis[(D-gluconoylamino)methyl]-3-amino] propyl]-D-gluconamide (6). Pentaerythrityl tetramine tetrahydrochloride $^{22} 5$ (14 g; $0.051 \mathrm{~mol}$ ) was suspended in a mixture of DMF $(170 \mathrm{~mL})$ and $\mathrm{Et}_{3} \mathrm{~N}(25.4 \mathrm{~mL} ; 0.184 \mathrm{mmol})$. A solution of $\delta$-gluconolactone 2 (32.7 g; $0.184 \mathrm{~mol})$ in DMF $(195 \mathrm{~mL})$ was slowly added dropwise $(1.5 \mathrm{~h})$ at room temperature. The mixture was stirred at room temperature for 4 days. The reaction mixture was filtered and concentrated at reduce pressure. The residue was treated with $\mathrm{MeCN}$ to give a precipitate which was filtered and washed with MeCN. The solid was dried to give 6 as a white solid and as hydrochloride salt (30.5 g; $0.046 \mathrm{mmol}$ ), yield 90\%; $R_{\mathrm{f}} 0.44$ (eluent $\mathrm{MeOH} / 25 \% \mathrm{NH}_{4} \mathrm{OH} 7: 3$ ); ${ }^{1} \mathrm{H}$ NMR $\left(600 \mathrm{MHz}, \mathrm{D}_{2} \mathrm{O}\right) \delta 4.35(\mathrm{~m}, 3 \mathrm{H}), 4.06(\mathrm{dt}, J=9.5,3.2 \mathrm{~Hz}, 3 \mathrm{H}), 3.75$ (m, 6H), 3.69 (m, 3H), 3.60 (dd, $J=11.8,6.3 \mathrm{~Hz}, 3 \mathrm{H}), 3.21-3.10$ (m, 6H), 3.06-2.96 (m, 2H); ${ }^{13} \mathrm{C}$ NMR (151 MHz, D $\left.\mathrm{D}_{2} \mathrm{O}\right) \delta 176.55$ (CO), 175.99 (CO), 74.04 (C-2), 73.91 (C-2'), 72.95 (C-3), 72.74 $\left(\mathrm{C}-3^{\prime}\right), 71.52$ (C-4), 70.83 (C-5), $70.68\left(\mathrm{C}-5^{\prime}\right), 62.96$ (C-6), 62.93 $\left(\mathrm{C}-6^{\prime}\right), 44.86(\mathrm{C}), 38.59\left(\mathrm{CH}_{2} \mathrm{~N}\right), 38.47\left(\mathrm{CH}_{2} \mathrm{~N}\right)$. ESI-HRMS $(\mathrm{m} / \mathrm{z})$ : $667.2175\left(\mathrm{M}+\mathrm{H}^{+}\right)$(calcd 667.2880).

Synthesis of $N, N$-bis [[[2,2-bis[(D-gluconoylamino)methyl]-3amino]propyl]-D-gluconamide]-2-oxoethyl]amino] ethyl]glycine (L2). $N, N^{\prime}$-Bis-[2-(2,6-dioxo-4-morpholinyl)ethyl]glycine (DTPA- bis-anhydride $)^{21} 4$ (0.19 g; $\left.0.54 \mathrm{mmol}\right)$ was added to a solution of $6(0.8 \mathrm{~g} ; 1.20 \mathrm{mmol})$ in DMSO $(5 \mathrm{~mL})$ and stirred at $50{ }^{\circ} \mathrm{C}$ for $8 \mathrm{~h}$. After cooling at room temperature, the reaction mixture was diluted with $\mathrm{CH}_{2} \mathrm{Cl}_{2}(50 \mathrm{~mL})$; the precipitate was filtered, washed with $\mathrm{CH}_{2} \mathrm{Cl}_{2}(200 \mathrm{~mL})$ then lyophilized to remove the residual DMSO. L2 was obtained as white solid (0.64 g; $0.38 \mathrm{mmol}$ ), yield 70\%. ${ }^{1} \mathrm{H}$ NMR (300 MHz, $\left.\mathrm{D}_{2} \mathrm{O}\right) \delta 4.18(\mathrm{~m}, 4 \mathrm{H})$, $3.94(\mathrm{~d}, J=3.2 \mathrm{~Hz}, 2 \mathrm{H}), 3.86-3.73(\mathrm{~m}, 6 \mathrm{H}), 3.65-3.54(\mathrm{~m}, 8 \mathrm{H})$, $3.51(\mathrm{~m}, 8 \mathrm{H}), 3.45-3.32(\mathrm{~m}, 8 \mathrm{H}), 3.06-2.77$ (m, 6H), $2.51(\mathrm{~s}, 18 \mathrm{H})$, $2.29(\mathrm{~m}, 6 \mathrm{H}), 0.78(\mathrm{t}, J=7.2 \mathrm{~Hz}, 4 \mathrm{H}) .{ }^{13} \mathrm{C} \mathrm{NMR}\left(75 \mathrm{MHz}, \mathrm{D}_{2} \mathrm{O}, \mathrm{pH}\right.$ = 10) $\delta 179.4,173.7,168.1,74.8,74.7,73.9,71.9,71.4,70.9,70.3$, 63.0, 45.2, 38.5, 9.9. ESI-HRMS (m/z): $1690.6211\left(\mathrm{M}+\mathrm{H}^{+}\right)$(calcd 1690.6865).

Synthesis of $(\mathrm{N}-[[2,2-\mathrm{bis}[\mathrm{D}-$ gluconoylamino $)$ methyl]-3-tertbutoxycarbonylamino]propyl]-D-gluconamide (7). Compound 6 $(30.0 \mathrm{~g}, 45.0 \mathrm{mmol})$ was dissolved in DMF $(400 \mathrm{~mL})$ and a solution of (Boc) $)_{2} \mathrm{O}(17.2 \mathrm{~g} ; 65.2 \mathrm{mmol})$ in DMF $(100 \mathrm{~mL})$ was slowly added dropwise. Then, tetramethylammonium hydroxide $(8.15 \mathrm{~g}, 45.0 \mathrm{mmol})$ was added and the mixture was stirred at room temperature for 2 days. The solution was concentrated at reduced pressure and the residue was treated with $\mathrm{CH}_{2} \mathrm{Cl}_{2}$ to give a precipitate which was filtered and washed with $\mathrm{H}_{2} \mathrm{O}(100 \mathrm{~mL})$ and $\mathrm{CH}_{3} \mathrm{OH}(100 \mathrm{~mL})$. The solid so obtained was dried to give 7 (25 g, $32.6 \mathrm{mmol}$ ), yield: $72 \% .{ }^{1} \mathrm{H}$ NMR $\left(600 \mathrm{MHz}, \mathrm{D}_{2} \mathrm{O}\right) \delta 4.35(\mathrm{~d}, J=2.7 \mathrm{~Hz}, 3 \mathrm{H}), 4.07(\mathrm{t}, J=3.1 \mathrm{~Hz}, 3 \mathrm{H})$, $3.75(\mathrm{~m}, 6 \mathrm{H}), 3.69(\mathrm{~m}, 3 \mathrm{H}), 3.61(\mathrm{dd}, J=11.8,6.4 \mathrm{~Hz}, 3 \mathrm{H}), 3.12(\mathrm{~s}$, 15H), $3.02(\mathrm{~m}, 6 \mathrm{H}), 2.85(\mathrm{~m}, 2 \mathrm{H}), 1.41(\mathrm{~s}, 9 \mathrm{H}) ;{ }^{13} \mathrm{C}$ NMR (151 MHz, $\mathrm{D}_{2} \mathrm{O}$ ) $\delta 175.79$ (CO), 158.81 (CO), 81.88 (C), 74.06 (C-2), 72.94 (C-3), 71.52 (C-4), 70.69 (C-5), 62.97 (C-6), 55.67, $45.52(\mathrm{C}), 39.94\left(\mathrm{CH}_{2} \mathrm{~N}\right), 38.72\left(\mathrm{CH}_{2} \mathrm{~N}\right), 28.07\left(\mathrm{CH}_{3}\right)$. ESI-HRMS $(\mathrm{m} / \mathrm{z}): 789.3003\left(\mathrm{M}+\mathrm{Na}^{+}\right)$(calcd 789.3229).

Synthesis of $(\mathrm{N}$-[[2,2-bis[2,3,4,5,6-penta-O-acetyl-D-gluconoylamino)methyl]-3-tert-butoxycarbonylamino]propyl]-2,3,4,5,6penta-O-acetyl-D-gluconamide (8). To a suspension of compound 7 (10.0 g; $13.0 \mathrm{mmol})$ in $\mathrm{Ac}_{2} \mathrm{O}(186 \mathrm{~mL} ; 1.97 \mathrm{~mol})$, pyridine (25.7 $\mathrm{g} ; 326 \mathrm{mmol}$ ) was added at room temperature. The mixture was then heated to $90{ }^{\circ} \mathrm{C}$ to dissolve the reagents, then cooled at room temperature. After 1 day at room temperature, the mixture was concentrated at reduce pressure and the residue was dissolved in EtOAc $(200 \mathrm{~mL})$ and washed with water $(200 \mathrm{~mL})$ and with $10 \%$ aqueous $\mathrm{NaHCO}_{3}(200 \mathrm{~mL})$. The organic phase was dried $\left(\mathrm{Na}_{2} \mathrm{SO}_{4}\right)$ and evaporated to give 8 (15 g; $10.7 \mathrm{mmol}$ ), yield: $82 \%,{ }^{1} \mathrm{H}$ NMR (600 MHz, $\left.\mathrm{CDCl}_{3}\right) \delta 8.21$ (s, $1 \mathrm{H}), 7.81(\mathrm{~s}, 2 \mathrm{H}), 6.00(\mathrm{~s}, 1 \mathrm{H}), 5.65(\mathrm{~m}, 3 \mathrm{H}), 5.45(\mathrm{~m}, 3 \mathrm{H}), 5.26$ $(\mathrm{m}, 3 \mathrm{H}), 5.07(\mathrm{~m}, 3 \mathrm{H}), 4.31(\mathrm{~m}, 3 \mathrm{H}), 4.17$ (br m, 3H), $3.37(\mathrm{~m}$, $4 \mathrm{H}), 3.22(\mathrm{~m}, 2 \mathrm{H}), 3.04(\mathrm{~m}, 2 \mathrm{H}), 2.29,2.10,2.06(\mathrm{~m}, 45 \mathrm{H}), 1.42(\mathrm{~s}$, 9H). ${ }^{13} \mathrm{C}$ NMR (151 MHz, $\mathrm{CDCl}_{3}$ ) $\delta 170.84$ (CO), 170.11 (CO), 170.04 (CO), 158.25 (CO), 80.26 (C), 71.50 (C-2), 70.43 (C-3), 70.28 (C-4), 69.23 (C-5), 61.68 (C-6), 39.65, $28.66\left(\mathrm{CH}_{3}\right), 21.09$ $\left(\mathrm{CH}_{3}\right), 21.04\left(\mathrm{CH}_{3}\right), 20.92\left(\mathrm{CH}_{3}\right), 20.64\left(\mathrm{CH}_{3}\right)$; ESI-HRMS $(\mathrm{m} / \mathrm{z})$ : 1419.4123 $\left(\mathrm{M}+\mathrm{Na}^{+}\right)$(calcd 1419.4814).

Synthesis of $(\mathrm{N}$-[[2,2-bis[2,3,4,5,6-penta-O-acetyl-D-gluconoylamino)methyl]-3-amino]propyl]-2,3,4,5,6-penta-O-acetyl-D-gluconamide (9). Trifluoroacetic acid (3.67 g; $32.0 \mathrm{mmol}$ ) was added to a solution of compound 8 (4.50 g; $3.20 \mathrm{mmol})$ in $\mathrm{CH}_{2} \mathrm{Cl}_{2}(60 \mathrm{~mL})$. After 3 days at room temperature, further TFA $(1.82 \mathrm{~g} ; 16.0 \mathrm{mmol})$ was added to the reaction mixture. After 
further 4 days at room temperature, the solvents were removed under reduced pressure and the residue was dissolved in $\mathrm{CH}_{2} \mathrm{Cl}_{2}(7 \mathrm{~mL})$ and TFA $(5.49 \mathrm{~g} ; 48.0 \mathrm{mmol})$. The mixture was stirred at room temperature for 1 day, then evaporated under reduced pressure. The residue was dissolved in $\mathrm{CH}_{2} \mathrm{Cl}_{2}(10 \mathrm{~mL})$ and evaporated several times affording 9 as a white solid and as trifluoroacetic salt $(3.00 \mathrm{~g} ; 2.13 \mathrm{mmol})$, yield: 67\%; $R_{\mathrm{f}} 0.59$ (eluent EtOAc/ $n$-hexane $8: 2$ ); ${ }^{1} \mathrm{H}$ NMR (400 MHz, $\left.\mathrm{CDCl}_{3}\right) \delta 8.27$ $(\mathrm{s}, 1 \mathrm{H}), 7.78(\mathrm{~s}, 2 \mathrm{H}), 7.34(\mathrm{~s}, 2 \mathrm{H}), 5.60(\mathrm{~m}, 3 \mathrm{H}), 5.46(\mathrm{~m}, 3 \mathrm{H}), 5.24$ $(\mathrm{d}, J=3.3 \mathrm{~Hz}, 3 \mathrm{H}), 5.09(\mathrm{td}, J=6.0,3.2 \mathrm{~Hz}, 3 \mathrm{H}), 4.34(\mathrm{~m}, 3 \mathrm{H})$, 4.16 (dd, $J=12.4,5.8 \mathrm{~Hz}, 3 \mathrm{H}), 3.02(\mathrm{~m}, 6 \mathrm{H}), 2.70(\mathrm{~s}, 2 \mathrm{H}), 2.24$, 2.13, 2.09, 2.07 (s, 45H). ${ }^{13} \mathrm{C}$ NMR (101 MHz, $\left.\mathrm{CDCl}_{3}\right) \delta 170.99$ (CO), 170.61 (CO), 170.47 (CO), 72.46 (C-2), 70.07 (C-3), 69.37 (C-4), 69.07 (C-5), 62.00 (C-6), 45.20 (C), $38.96\left(\mathrm{CH}_{2} \mathrm{~N}\right), 38.49$ $\left(\mathrm{CH}_{2} \mathrm{~N}\right), 21.01\left(\mathrm{CH}_{3}\right), 20.96\left(\mathrm{CH}_{3}\right), 20.72\left(\mathrm{CH}_{3}\right), 20.59\left(\mathrm{CH}_{3}\right)$; ESI-HRMS $(\mathrm{m} / \mathrm{z}): 1297.3996\left(\mathrm{M}+\mathrm{H}^{+}\right)$(calcd 1297.4470).

Synthesis of (dibenzylamino)methylphosphonic acid di-tertbutyl ester (18). Paraformaldehyde (2.14 g; $71.2 \mathrm{mmol})$ was added to a solution of dibenzylamine (12.7 g; $64.5 \mathrm{mmol})$ in MeCN (130 mL). The suspension was heated to $80{ }^{\circ} \mathrm{C}$ for $1 \mathrm{~h}$, then the resulting solution was cooled to rt. A solution of tertbutyl phosphite (71.2\% of purity, $25 \mathrm{~g} ; 71.2 \mathrm{mmol}$ ) in MeCN was added dropwise over $25 \mathrm{~min}$ to the reaction mixture and the solution was stirred at room temperature for $22 \mathrm{~h}$. The solvent was evaporated under vacuum and $0.1 \mathrm{~N} \mathrm{HCl}(320 \mathrm{~mL})$ was added to the residue. The suspension was extracted with $\mathrm{CH}_{2} \mathrm{Cl}_{2}$ $(3 \times 150 \mathrm{~mL})$ and the combined organic phases washed with water $(3 \times 150 \mathrm{ml})$, dried $\left(\mathrm{Na}_{2} \mathrm{SO}_{4}\right)$ and evaporated in vacuo. The crude $(27.3 \mathrm{~g})$ was purified by chromatography on silica gel (15: 85 EtOAc/petroleum ether; $R_{\mathrm{f}} 0.2$ ) and the desired product was obtained (12.4 g, $30.8 \mathrm{mmol})$ as a colourless oil. Yield: $47.7 \% .{ }^{1} \mathrm{H}-\mathrm{NMR}\left(\mathrm{CDCl}_{3}\right) 400 \mathrm{MHz} \delta=7.43(\mathrm{~d}, 4 \mathrm{H}, J=7.2 \mathrm{~Hz}$, $\left.\mathrm{H}_{\mathrm{ar}}\right), 7.32\left(\mathrm{t}, 4 \mathrm{H}, J=7.2 \mathrm{~Hz}, \mathrm{H}_{\mathrm{ar}}\right), 7.24\left(\mathrm{~m}, 2 \mathrm{H}, \mathrm{H}_{\mathrm{ar}}\right), 3.94(\mathrm{~s}, 4 \mathrm{H}$, $\mathrm{CH}_{2} \mathrm{Ph}$ ), 2.79 (d, 2H, $\left.\mathrm{J}=10.2 \mathrm{~Hz}, \mathrm{CH}_{2} \mathrm{P}\right), 1.49$ (s, 18H, $\mathrm{CCH}_{3}$ ). ${ }^{13} \mathrm{C}-\mathrm{NMR}\left(\mathrm{CDCl}_{3}\right) 100 \mathrm{MHz} \delta=139.6\left(C_{\mathrm{ar}}\right), 129.6-128.6-127.3$ $\left(\mathrm{CH}_{\mathrm{ar}}\right), 82.4\left(\mathrm{CCH}_{3}\right), 59.5\left(\mathrm{CH}_{2} \mathrm{Ph}\right), 52.5\left(\mathrm{CH}_{2} \mathrm{P}, J=163 \mathrm{~Hz}\right), 30.9$ $\left(\mathrm{CCH}_{3}\right) ;{ }^{31} \mathrm{P}-\mathrm{NMR}\left(\mathrm{CDCl}_{3}\right) 162 \mathrm{MHz} \delta=19.4$. MS (ESI+; MeOH): $m / z 404\left(\mathrm{M}+\mathrm{H}^{+}\right)$.

Synthesis of aminomethylphosphonic acid di-tert-butyl ester (19). (Dibenzylamino)methylphosphonic acid di-tert-butyl ester (33.3 g; $82.7 \mathrm{mmol}$ ) was dissolved in $\mathrm{MeOH}(500 \mathrm{~mL})$ and hydrogenated at atmospheric pressure on $\mathrm{Pd} / \mathrm{C} 10 \%$ (3.3 g). After $2 \mathrm{~h}$ the mixture was filtered through Millipore ${ }^{\circledR}$ apparatus $(0.5 \mu \mathrm{m})$ and the solution evaporated under vacuum. The crude $(18.4 \mathrm{~g})$ was used without any further purification. Quantitative yield. ${ }^{1} \mathrm{H}-\mathrm{NMR}\left(\mathrm{CDCl}_{3}\right) 400 \mathrm{MHz} \delta=2.81(\mathrm{~d}, 2 \mathrm{H}, J=10.2 \mathrm{~Hz}$, $\left.\mathrm{CH}_{2} \mathrm{P}\right), 1.49\left(\mathrm{~s}, 18 \mathrm{H}, \mathrm{CCH}_{3}\right) .{ }^{13} \mathrm{C}-\mathrm{NMR}\left(\mathrm{CDCl}_{3}\right) 100 \mathrm{MHz} \delta=$ $83.2\left(\mathrm{CCH}_{3}\right), 40.6\left(\mathrm{CH}_{2} \mathrm{P}, J=153 \mathrm{~Hz}\right), 29.5\left(\mathrm{CCH}_{3}\right) ;{ }^{31} \mathrm{P}-\mathrm{NMR}$ $\left(\mathrm{CDCl}_{3}\right) 162 \mathrm{MHz} \delta=21.0$. MS (ESI+; $\left.\mathrm{MeOH}\right): \mathrm{m} / z 224\left(\mathrm{M}+\mathrm{H}^{+}\right)$.

Synthesis of L-aspartic acid, 1-tert-butyl-4-benzylester (11). Perchloric acid (70\% aq.; $19.28 \mathrm{~g} ; 0.134 \mathrm{~mol}$ ) was dropped into a suspension of L-aspartic acid 4-(phenylmethyl) ester (25 g; $0.112 \mathrm{~mol})$ in tert-butyl acetate $(515 \mathrm{~mL} ; 3822 \mathrm{~mol})$ stirred at room temperature. After $18 \mathrm{~h}$ at room temperature the obtained clear solution was diluted with $\mathrm{H}_{2} \mathrm{O}(470 \mathrm{~mL})$ and the phases were separated; the aqueous phase was extracted with EtOAc (2 $\times 235 \mathrm{~mL})$. The organic phases were collected and washed with $5 \%$ aq. $\mathrm{NaHCO}_{3}(2 \times 250 \mathrm{~mL})$ and $\mathrm{H}_{2} \mathrm{O}(2 \times 200 \mathrm{~mL})$; the new aqueous phases were collected and extracted with EtOAc $(3 \times 100 \mathrm{~mL})$. All organic phases were collected, dried over $\mathrm{Na}_{2} \mathrm{SO}_{4}$ and evaporated to obtain 11 (27 g; $\left.0.097 \mathrm{~mol}\right)$ as a pale yellow oil. Yield 86.6\%. TLC (silica gel; eluent: EtOAC; $R_{\mathrm{f}} 0,57$ ). ${ }^{1} \mathrm{H}-\mathrm{NMR}\left(\mathrm{CDCl}_{3}\right) 400 \mathrm{MHz} \delta=7.31\left(\mathrm{~m}, 5 \mathrm{H}, \mathrm{H}_{\mathrm{ar}}\right), 5.14(\mathrm{~s}, 2 \mathrm{H}$, $\left.\mathrm{CH}_{2} \mathrm{Ph}\right), 3.68\left(\mathrm{t}, 1 \mathrm{H}, \mathrm{J}=6.3 \mathrm{~Hz}, \mathrm{CHNH} \mathrm{N}_{2}\right), 2.77$ and $2.66(\mathrm{dd}, 2 \mathrm{H}$, $\left.J_{1}=16.3 \mathrm{~Hz}, J_{2}=4.9 \mathrm{~Hz}, \mathrm{CH}_{2} \mathrm{CO}_{2} \mathrm{Bn}\right), 1.76\left(\mathrm{bs}, 2 \mathrm{H}, \mathrm{NH}_{2}\right), 1.40(\mathrm{~s}$, 9H, $\left.\mathrm{CCH}_{3}\right) .{ }^{13} \mathrm{C}-\mathrm{NMR}\left(\mathrm{CDCl}_{3}\right) 100 \mathrm{MHz} \delta=173.7\left(\mathrm{CO}_{2} \mathrm{Bn}\right), 171.5$ $\left(\mathrm{CO}_{2} \mathrm{tBu}\right), 136.1\left(C_{\mathrm{ar}}\right), 128.7\left(\mathrm{CH}_{\mathrm{ar}}\right), 81.8\left(\mathrm{CCH}_{3}\right), 66.8\left(\mathrm{CH}_{2} \mathrm{Ph}\right)$, $52.2\left(\mathrm{CHNH}_{2}\right), 39.6\left(\mathrm{CH}_{2} \mathrm{CO}_{2} \mathrm{Bn}\right), 28.3\left(\mathrm{CCH}_{3}\right)$. $\mathrm{MS}$ (ESI+; $\left.\mathrm{MeOH}\right)$ : $m / z 280.2\left(\mathrm{M}+\mathrm{H}^{+}\right) ; 302.2\left(\mathrm{M}+\mathrm{Na}^{+}\right)$.

Synthesis of $\mathrm{N}$-2-(t-butoxycarbonylmethyl)-L-aspartic acid, 1-tert-butyl-4-benzylester (12). A mixture of L-aspartic acid, 1- $t$ butyl-4-benzylester 11 (27 g; $0.0967 \mathrm{~mol}$ ), $t$-butyl bromoacetate (20.00 g; $0.102 \mathrm{~mol})$, acetonitrile $(160 \mathrm{~mL})$ and $2 \mathrm{M}$ phosphate buffer pH 8 (80 mL) was vigorously stirred at room temperature; after $18 \mathrm{~h}$ the phases was separated and the organic phase was evaporated. The residue thus obtained was dissolved in EtOAc $(300 \mathrm{~mL})$ and washed with $\mathrm{H}_{2} \mathrm{O}(2 \times 150 \mathrm{~mL})$ and brine $(2 \times$ $150 \mathrm{~mL}$ ). After drying over $\mathrm{Na}_{2} \mathrm{SO}_{4}$, the organic solution was evaporated to give a crude $(34 \mathrm{~g})$ that was purified by flashchromatography [silica gel; eluent: $4: 1 n$-hexane/EtOAc; $R_{\mathrm{f}}$ 0,34] to obtain $29.1 \mathrm{~g}$ of 1 . (Yield: 76.5\%) ${ }^{1} \mathrm{H}-\mathrm{NMR}\left(\mathrm{CDCl}_{3}\right)$ $400 \mathrm{MHz} \delta=7.32\left(\mathrm{~m}, 5 \mathrm{H}, \mathrm{H}_{\mathrm{ar}}\right), 5.14\left(\mathrm{~s}, 2 \mathrm{H}, \mathrm{CH}_{2} \mathrm{Ph}\right), 3.59(\mathrm{t}, 1 \mathrm{H}$, $J=6.3 \mathrm{~Hz}, \mathrm{CHNH}$ ), $3.36\left(\mathrm{dd}, 2 \mathrm{H}, J_{1}=17.0 \mathrm{~Hz}, \mathrm{CH}_{2} \mathrm{CO}_{2} t \mathrm{Bu}\right), 2.78$ and $2.71\left(\mathrm{dd}, 2 \mathrm{H}, J_{1}=16.0 \mathrm{~Hz}, J_{2}=6.4 \mathrm{~Hz}, \mathrm{CH}_{2} \mathrm{CO}_{2} \mathrm{Bn}\right), 1.48$ and $1.44\left(\mathrm{~s}, 18 \mathrm{H}, \mathrm{CCH}_{3}\right) .{ }^{13} \mathrm{C}-\mathrm{NMR}\left(\mathrm{CDCl}_{3}\right) 100 \mathrm{MHz} \delta=172.3$ $\left(\mathrm{CO}_{2} \mathrm{Bn}\right), 171.3,171.1\left(\mathrm{CO}_{2} t \mathrm{Bu}, 2 \mathrm{C}\right), 136.1\left(C_{\mathrm{ar}}\right), 128.9,128.6$ $\left(\mathrm{CH}_{\mathrm{ar}}\right), 82.1,81.6\left(\mathrm{CCH}_{3}\right), 66.9\left(\mathrm{CH}_{2} \mathrm{Ph}\right), 58.0(\mathrm{CHNH}), 50.3$ $\left(\mathrm{CH}_{2} \mathrm{CO}_{2} t \mathrm{Bu}\right), 38.5\left(\mathrm{CH}_{2} \mathrm{CO}_{2} \mathrm{Bn}\right), 28.6,28.3\left(\mathrm{CCH}_{3}\right)$. ESI-HRMS $(\mathrm{m} / \mathrm{z})$ : $394.2167\left(\mathrm{M}+\mathrm{H}^{+}\right)$(calcd 394.2230).

Synthesis of $N$-2-bromoethyl- $N$-2-(t-butoxycarbonylmethyl)-Laspartic acid, 1-tert-butyl-4-benzylester (13). 2-Bromoethyl trifluoromethanesulfonate $^{29}$ (34.93 g; $0.136 \mathrm{~mol}, 1.7 \mathrm{eq}$.) was slowly dropped into a solution of compound 12 (31.5 g; $0.08 \mathrm{~mol}$ ) and 2,6-lutidine ( $27 \mathrm{~g} ; 0.25 \mathrm{~mol}, 3.1 \mathrm{eq}$.) in toluene $(450 \mathrm{~mL})$ stirred at $-15{ }^{\circ} \mathrm{C}$ under nitrogen atmosphere. The reaction mixture was stirred at room temperature for $22 \mathrm{~h}$ then diluted with $\mathrm{H}_{2} \mathrm{O}(200 \mathrm{~mL})$ and extracted with EtOAc $(200 \mathrm{~mL})$. The organic solution was dried over $\mathrm{Na}_{2} \mathrm{SO}_{4}$ and evaporated to give a crude $(33 \mathrm{~g}$ ) that was purified by chromatography [silica gel, eluent: 7 : $3 n$-hexane/iPr $\left.2 \mathrm{O}, R_{\mathrm{f}} 0,44\right]$ to obtain $13(24,9 \mathrm{~g}$; $0,05 \mathrm{~mol})$ as a pale yellow oil. Yield $62.4 \% .{ }^{1} \mathrm{H}-\mathrm{NMR}\left(\mathrm{CDCl}_{3}\right)$ $400 \mathrm{MHz} \delta=7.37\left(\mathrm{~m}, 5 \mathrm{H}, \mathrm{H}_{\mathrm{ar}}\right), 5.15\left(\mathrm{~s}, 2 \mathrm{H}, \mathrm{CH}_{2} \mathrm{Ph}\right), 3.87(\mathrm{t}, 1 \mathrm{H}$, $J=7.4 \mathrm{~Hz}, \mathrm{CHN}), 3.40,3.15\left(\mathrm{~m}, 6 \mathrm{H}, \mathrm{CH}_{2} \mathrm{CH}_{2} \mathrm{Br}\right.$ and $\left.\mathrm{CH}_{2} \mathrm{CO}_{2} t \mathrm{Bu}\right)$, 2.85 and $2.69\left(\mathrm{dd}, 2 \mathrm{H}, J_{1}=16.0 \mathrm{~Hz}, J_{2}=7.4 \mathrm{~Hz}, \mathrm{CH}_{2} \mathrm{CO}_{2} \mathrm{Bn}\right), 1.46$ and $1.44\left(\mathrm{~s}, 18 \mathrm{H}, \mathrm{CCH}_{3}\right) .{ }^{13} \mathrm{C}-\mathrm{NMR}\left(\mathrm{CDCl}_{3}\right) 100 \mathrm{MHz} \delta=171.0$ $\left(\mathrm{CO}_{2} \mathrm{Bn}\right.$ and $\left.\mathrm{CO}_{2} \mathrm{tBu}, 3 \mathrm{C}\right), 136.1\left(C_{\mathrm{ar}}\right), 128.9,128.7\left(\mathrm{CH}_{\mathrm{ar}}\right), 82.4$, $81.5\left(\mathrm{CCH}_{3}\right), 67.0\left(\mathrm{CH}_{2} \mathrm{Ph}\right), 62.9(\mathrm{CHN}), 56.1,54.9\left(\mathrm{NCH}_{2}, 2 \mathrm{C}\right)$, $36.7\left(\mathrm{CH}_{2} \mathrm{CO}_{2} \mathrm{Bn}\right), 30.8\left(\mathrm{CH}_{2} \mathrm{Br}\right), 28.5\left(\mathrm{CCH}_{3}\right)$. ESI-HRMS $(\mathrm{m} / \mathrm{z})$ : $500.1206\left(\mathrm{M}+\mathrm{H}^{+}\right)$(calcd 500.1648).

Synthesis of $N, N^{\prime}-[[[[$ bis(1,1-dimethylethoxy)phosphinyl $]$ methyl]imino]di-2,1-ethanediyl] bis[N-[2-(1,1-dimethylethoxy)-2oxoethyl]-L-aspartic acid 1,1'-bis(1,1-dimethylethyl) 4,4'bis(phenylmethyl) ester (14). A solution of bromo-derivative 13 (4.11 g; $8.22 \mathrm{mmol})$ in acetonitrile $(20 \mathrm{~mL})$ was slowly dropped 
into an emulsion of aminomethylphosphonic acid di-tert-butyl ester 19 (916 $\mathrm{mg} ; 4.11 \mathrm{mmol}$ ) in acetonitrile $(10 \mathrm{~mL})$ and $2 \mathrm{M}$ phosphate buffer $\mathrm{pH} 8(20 \mathrm{~mL})$ over 8 hours under vigorous stirring. After $22 \mathrm{~h}$, the phases were separated and the aqueous layer was extracted with EtOAc $(2 \times 30 \mathrm{~mL})$. The organic layer was evaporated. The oily residue was dissolved with EtOAc $(20 \mathrm{~mL})$, and the solution was washed with $1: 1$ water/brine $(2 \times$ $30 \mathrm{~mL}$ ) and dried over $\mathrm{Na}_{2} \mathrm{SO}_{4}$. The crude ( $\left.4.49 \mathrm{~g}\right)$ was purified by silica gel chromatography (silica gel; EtOAc/petroleum ether $4: 6 ; R_{\mathrm{f}} 0.32$ ). Compound 14 was obtained $(1.86 \mathrm{~g} ; 1.75 \mathrm{mmol})$ as a yellow oil. Yield $42.4 \% .{ }^{1} \mathrm{H}-\mathrm{NMR}\left(\mathrm{CDCl}_{3}\right) 400 \mathrm{MHz} \delta=7.32(\mathrm{~m}$, $10 \mathrm{H}, \mathrm{H}_{\mathrm{ar}}$ ), 5.09 (s, $\left.4 \mathrm{H}, \mathrm{CH}_{2} \mathrm{Ph}\right), 3.80(\mathrm{dd}, 2 \mathrm{H}, J=3.6 \mathrm{~Hz}, \mathrm{CHN}$ ), $3.35\left(\mathrm{~s}, 4 \mathrm{H}, \mathrm{CH}_{2} \mathrm{CO}_{2} t \mathrm{Bu}\right), 2.82-2.62\left(\mathrm{~m}, 14 \mathrm{H}, \mathrm{NCH}_{2} \mathrm{CH}_{2} \mathrm{~N}, \mathrm{NCH}_{2} \mathrm{P}\right.$ and $\left.\mathrm{CH}_{2} \mathrm{CO}_{2} \mathrm{Bn}\right), 1.46$ and $1.41\left(\mathrm{~s}, 54 \mathrm{H}, \mathrm{CCH}_{3}\right) \cdot{ }^{13} \mathrm{C}-\mathrm{NMR}\left(\mathrm{CDCl}_{3}\right)$ $100 \mathrm{MHz} \delta=171.3\left(\mathrm{CO}_{2} \mathrm{Bn}\right.$ and $\left.\mathrm{CO}_{2} t \mathrm{Bu}, 6 \mathrm{C}\right), 136.3\left(C_{\mathrm{ar}}\right), 128.9$, 128.6 $\left(\mathrm{CH}_{\mathrm{ar}}\right), 82.5,81.8,81.0\left(\mathrm{CCH}_{3}\right), 66.7\left(\mathrm{CH}_{2} \mathrm{Ph}\right), 62.2(\mathrm{NCH})$, $55.0\left(\mathrm{CH}_{2} \mathrm{CO}_{2} t \mathrm{Bu}\right), 54.7,51.2\left(\mathrm{NCH}_{2} \mathrm{CH}_{2} \mathrm{~N}\right), 52.2\left(\mathrm{CH}_{2} \mathrm{P}\right), 36.5$ $\left(\mathrm{CH}_{2} \mathrm{CO}_{2} \mathrm{Bn}\right), 30.9$ and $28.5\left(\mathrm{CCH}_{3}\right) .{ }^{31} \mathrm{P}-\mathrm{NMR}\left(\mathrm{CDCl}_{3}\right) 162 \mathrm{MHz}$ $\delta=18.6$. ESI-HRMS $(\mathrm{m} / \mathrm{z}): 1062.5503\left(\mathrm{M}+\mathrm{H}^{+}\right)($calcd 1062.6031).

Synthesis of $N, N^{\prime}$-[[[[bis(1,1-dimethylethoxy)phosphinyl] methyl]imino]di-2,1-ethanediyl $]$ bis $[N$-[2-(1,1-dimethylethoxy)-2oxoethyl]-L-aspartic acid 1,1'-bis(1,1-dimethylethyl) ester, (15). Compound 14 (973 mg; $1.10 \mathrm{mmol}$ ) was dissolved in methanol $(50 \mathrm{~mL})$ and hydrogenated at atmospheric pressure on $10 \%$ $\mathrm{Pd} / \mathrm{C}(50 \mathrm{mg})$. After $30 \mathrm{~min}$ the reaction mixture was filtered through Millipore apparatus ${ }^{\circledR}(0.5 \mathrm{~m}$ filter $)$ and the solution evaporated under vacuum. The crude (725 mg) was used in the next step without any further purification. 1H-NMR $\left(\mathrm{CDCl}_{3}\right)$ $400 \mathrm{MHz} \delta \delta=3.89(\mathrm{~m}, 2 \mathrm{H}, \mathrm{CHN}), 3.49-3.36(\mathrm{~m}, 4 \mathrm{H}$, $\mathrm{CH} 2 \mathrm{CO} 2 \mathrm{tBu}), 3.25-2.95$ (m, 10H, NCH2CH2N, NCH2P) 2.75 $(\mathrm{CH} 2 \mathrm{CO} 2 \mathrm{H}), 1.50$ and $1.46(\mathrm{~s}, 54 \mathrm{H}, \mathrm{CCH} 3) .13 \mathrm{C}-\mathrm{NMR}\left(\mathrm{CDCl}_{3}\right)$ $100 \mathrm{MHz} \delta \delta=173.0(\mathrm{COOH}), 170.8,170.2(\mathrm{CO} 2 \mathrm{tBu}, 4 \mathrm{C}), 84.2$, 82.7, 82.2 (CCH3), $61.7(\mathrm{NCH}), 54.5\left(\mathrm{CH} 2 \mathrm{CO}_{2} t \mathrm{Bu}\right), 54.0,50.1$ $\left(\mathrm{NCH}_{2} \mathrm{CH}_{2} \mathrm{~N}\right), 51.8\left(\mathrm{CH}_{2} \mathrm{P}, J=155 \mathrm{~Hz}\right), 35.6\left(\mathrm{CH}_{2} \mathrm{CO}_{2} \mathrm{H}\right), 30.9$ and $28.5\left(\mathrm{CCH}_{3}\right) \cdot{ }^{31} \mathrm{P}-\mathrm{NMR}\left(\mathrm{CDCl}_{3}\right) 162 \mathrm{MHz} \delta=15.0$. ESI-HRMS $(\mathrm{m} / \mathrm{z})$ : 882.4855 $\left(\mathrm{M}+\mathrm{H}^{+}\right)$(calcd 882.5092).

Synthesis of compound (16). A solution of diacid 15 (4.91 g; $5.58 \mathrm{mmol}$ ), polyalcohol 9 (17.40 g; $13.38 \mathrm{mmol}, 2.4$ equivalents) and HATU ( $5.08 \mathrm{~g} ; 13.38 \mathrm{mmol})$ in $50 \mathrm{~mL}$ of DMF was brought to $0{ }^{\circ} \mathrm{C}$ with an ice bath in nitrogen atmosphere. To this solution, DIPEA (9.32 mL, $53.52 \mathrm{mmol}$, 9.6 eq.) was added keeping the temperature below $5{ }^{\circ} \mathrm{C}$. The mixture was kept under stirring at room temperature for $48 \mathrm{~h}$ monitoring the reaction by TLC (silica gel; $\mathrm{CHCl}_{3} / \mathrm{MeOH} 9: 1$ ), then the reaction solution was poured in ice, stirred for $30 \mathrm{~min}$ and filtered. The solid was washed with water, dissolved in chloroform and dried over $\mathrm{Na}_{2} \mathrm{SO}_{4}$. After filtration and solvent evaporation, the desired product was obtained as pale yellow gummy solid $(15.3 \mathrm{~g}, 80 \%$ yield). ( $R_{\mathrm{f}} 0.52$, silica, $\left.\mathrm{CHCl}_{3} / \mathrm{MeOH} 9: 1\right) .{ }^{1} \mathrm{H} \mathrm{NMR}(400 \mathrm{MHz}$, $\left.\mathrm{CDCl}_{3}\right) \delta 7.86(\mathrm{sb}, 8 \mathrm{H}), 5.61(\mathrm{~m}, 6 \mathrm{H}), 5.46(\mathrm{~m}, 6 \mathrm{H}), 5.31(\mathrm{~m}, 6 \mathrm{H})$, $4.97(\mathrm{~m}, 6 \mathrm{H}), 4.29(\mathrm{~m}, 6 \mathrm{H}), 4.16(\mathrm{~m}, 6 \mathrm{H}), 3.83(\mathrm{~m}, 2 \mathrm{H}, \mathrm{CHN})$, 3.60-2.75 (m, $\left.14 \mathrm{H}, \mathrm{CH}_{2} \mathrm{CO}_{2} t \mathrm{Bu}, \mathrm{NCH}_{2} \mathrm{CH}_{2} \mathrm{~N}, \mathrm{NCH}_{2} \mathrm{P}\right), 2.28(\mathrm{~s}$, $\left.16 \mathrm{H}, \mathrm{CCH}_{2} \mathrm{~N}\right), 2.07$ and $2.02\left(\mathrm{~m}, 90 \mathrm{H}, \mathrm{CH}_{3} \mathrm{COO}\right), 1.54$ and $1.46(\mathrm{~s}$, $\left.54 \mathrm{H}, \mathrm{CCH}_{3}\right) .{ }^{13} \mathrm{C}$ NMR $\left(101 \mathrm{MHz}, \mathrm{CDCl}_{3}\right) \delta 172.8,170.9,170.5$, 169.8, 169.6, 168.7, 81.4, 69.9, 68.9, 61.4, 45.8, 38.4, 30.7, 30.0, 28.3, 28.2, 20.7. ESI-HRMS $(\mathrm{m} / \mathrm{z}): 3439.2986\left(\mathrm{M}+\mathrm{H}^{+}\right)$(calcd 3439.3665).
Synthesis of compound (17). Ammonia was bubbled for $45 \mathrm{~min}$ into a solution of the fully protected ligand 16 (19.48 g) in methanol $(400 \mathrm{~mL})$ refrigerated with an ice bath. After $1 \mathrm{~h}$ the ice bath was removed, $\mathrm{CaCl}_{2}$ valve was applied and the solution was allowed to stir at room temperature for 9 days. Every two days more ammonia was bubbled for 10-15 min into the solution. The reaction was followed by TLC $\left(\mathrm{CHCl}_{3} / \mathrm{MeOH} 9: 1\right)$ and by MS until disappearance of any peaks related to partially acetylated product. Then, the solvent was evaporated in vacuum obtaining $18.1 \mathrm{~g}$ of the crude which was used without any further purification in the next deprotection step. ${ }^{1} \mathrm{H}$ NMR (400 MHz, $\left.\mathrm{D}_{2} \mathrm{O}\right) \delta 4.34$ (bs, 6H), 4.06 (bs, 6), 3.82-3.71 (m, 8H), $3.68(\mathrm{t}, J=6.8 \mathrm{~Hz}, 4 \mathrm{H}), 3.59(\mathrm{~m}, 4 \mathrm{H}), 2.94(\mathrm{bs}, 8 \mathrm{H}), 2.78(\mathrm{~s}, 4 \mathrm{H})$, $2.73(\mathrm{~s}, 2 \mathrm{H}), 1.42(\mathrm{~m}, 56 \mathrm{H}) .{ }^{13} \mathrm{C} \mathrm{NMR}\left(101 \mathrm{MHz}, \mathrm{CDCl}_{3}\right) \delta 171.9$, 171.5, 170.8, 170.7, 169.7, 82.4, 78.0, 70.9, 70.0, 62.4, 46.7, 39.2, 31.7, 31.0, 29.2. ESI-HRMS $(\mathrm{m} / \mathrm{z}): 2179.1102\left(\mathrm{M}+\mathrm{H}^{+}\right)$(calcd 2179.0495).

Synthesis of compound (L3). A round-bottomed flask containing the phosphonic proligand 17 (18.1 g, $8.3 \mathrm{mmol})$ was cooled with an ice bath; then a mixture of $\mathrm{CH}_{2} \mathrm{Cl}_{2} / \mathrm{TFA} 1: 1$ $(100 \mathrm{~mL})$ was added dropwise giving a yellow-brown solution. After $20 \mathrm{~min}$, the ice bath was removed and the solution was kept under stirring at room temperature for $16 \mathrm{~h}$. The solvent was removed and the residue was dissolved in dichloromethane $(5 \mathrm{~mL})$ and evaporated; this procedure was repeated four times. The crude was treated with $\mathrm{Et}_{2} \mathrm{O}$ to obtain the precipitation of a white solid which was filtered, dissolved in water and lyophilized. The slightly yellow solid was then re-dissolved in water, brought to $\mathrm{pH} 7$ by adding $2 \mathrm{M} \mathrm{NaOH}$ and lyophilized again. The solid obtained was recovered with $\mathrm{MeOH}$ and kept under stirring for $1 \mathrm{~h}$. The white solid formed was filtered and dried in vacuum to obtain $4.6 \mathrm{~g}$ ( $2.50 \mathrm{mmol}, 30 \%$ yield) of product. The methanolic solution was dried at the rotary evaporator and in vacuum to obtain $2.9 \mathrm{~g}$ of the mono-derivative as a yellow oil. ${ }^{1} \mathrm{H}$ NMR (400 MHz, $\mathrm{D}_{2} \mathrm{O}$ ) $\delta 4.39$ (bs, 6H), 4.10 (bs, 6H), 3.82-3.76 (m, 8H), 3.76-3.70 (m, 4H), 3.64 (dd, $J=11.6,6.3 \mathrm{~Hz}, 4 \mathrm{H}), 3.32$ (s, 4H), 3.07 (s, 8H), 2.96 (s, 2H). $\left.{ }^{13} \mathrm{C} \mathrm{NMR} \mathrm{(101} \mathrm{MHz,} \mathrm{CDCl}_{3}\right) \delta$ 171.9, 171.5, 170.8, 170.7, 169.7, 82.4, 78.0, 70.9, 70.0, 62.4, 46.7, 39.2, 31.7, 31.0, 29.2. ESI-HRMS (m/z): $1842.6012\left(\mathrm{M}+\mathrm{H}^{+}\right)$(calcd 1842.6739).

\section{Water proton relaxation measurements}

The longitudinal water proton relaxation rates were measured at $25{ }^{\circ} \mathrm{C}$ by using a Stelar Spinmaster (Stelar, Mede, Pavia, Italy) spectrometer operating at $0.5 \mathrm{~T}(21.5 \mathrm{MHz}$ Proton Larmor Frequency), by mean of the standard inversion-recovery technique. The temperature was controlled with a Stelar VTC-91 airflow heater equipped with a copper constantan thermocouple (uncertainty $0.1{ }^{\circ} \mathrm{C}$ ). The proton $1 / T_{1}$ NMRD profiles were measured at $25{ }^{\circ} \mathrm{C}$ on a fast field-cycling Stelar relaxometer over a continuum of magnetic field strengths from 0.00024 to $0.47 \mathrm{~T}$ (corresponding to $0.01-20 \mathrm{MHz}$ proton Larmor frequencies). The relaxometer operates under computer control with an absolute uncertainty in $1 / T_{1}$ of $\pm 1 \%$. Additional data points in the range $21.5-70 \mathrm{MHz}$ were obtained on the Stelar Spinmaster spectrometer. The concentration of the solutions used for the 
relaxometric characterization was determined by measuring the bulk magnetic-susceptibility shifts of the $t \mathrm{BuOH}$ signal.

\section{${ }^{17}$ O-NMR measurements}

Variable temperature ${ }^{17} \mathrm{O}-\mathrm{NMR}$ measurements were recorded at $2.1 \mathrm{~T}$ on a JEOL90 spectrometer, equipped with a $5 \mathrm{~mm}$ probe, by using a $\mathrm{D}_{2} \mathrm{O}$ external lock. The experimental settings were: spectral width $9000 \mathrm{~Hz}, 90^{\circ}$ pulse $(12 \mu \mathrm{s})$, acquisition time $10 \mathrm{~ms}$, 1024 scans and without sample spinning. Aqueous solutions containing $2.6 \%$ of ${ }^{17} \mathrm{O}$ isotope (Yeda, Israel) were used. The observed transverse relaxation rates $\left(R_{\text {2obs }}^{\mathrm{O}}\right)$ were calculated from the signal width at half-height $\left(\Delta \nu_{1 / 2}\right): R_{2 \mathrm{obs}}^{\mathrm{O}}=\pi \Delta \nu_{1 / 2}$. Paramagnetic contributions to the observed transversal relaxation rate $\left(R_{2 \mathrm{p}}\right)$ were calculated by subtracting from $R_{2 \mathrm{obs}}^{\mathrm{O}}$ the diamagnetic contribution measured at each temperature value on pure water enriched with $2.6 \%{ }^{17} \mathrm{O}$ isotope.

\section{Conclusions}

The synthesis of three novel DTPA derivatives bearing polyhydroxylated pendant arms is reported. While the two DTPA bisamides $\mathbf{L 1}$ and $\mathbf{L} 2$ with differently branched polygluconyl groups were easily synthesised from DTPA bis-anhydride, the monophosphonic P-DTPA ligand L3 was prepared by a multistep procedure which included the synthesis of a bisfunctionalized DTPA bifunctional ligand via the Rapoport reaction. The relaxivity of GdL1 and GdL2 were very low because DTPA-bisamides are characterized by slow water exchange rates of the coordinated water molecule. On the other hand, the relaxivity values measured for GdL3 over a wide range of imaging fields (0.5-3 Tesla) are among the highest till now reported for monomeric $\mathrm{Gd}(\mathrm{III})$ complexes with medium sized molecular weight ( $\sim 2000 \mathrm{Da})$. This finding makes GdL3 a very promising system for applications at the currently used magnetic fields of the clinical MRI scanners.

\section{Notes and references}

1 The Chemistry of Contrast Agents in Medical Magnetic Resonance Imaging, ed. A. Merbach, L. Helm and É. Tóth, John Wiley \& Sons Ltd, Chichester, 2nd edn, 2013.

2 (a) C. F. G. C. Geraldes and S. Laurent, Contrast Media Mol. Imaging, 2009, 4, 1; (b) P. Hermann, J. Kotek, V. Kubíček and I. Lukeš, Dalton Trans., 2008, 3027; (c) P. Caravan, J. J. Ellison, T. J. McMurry and R. B. Lauffer, Chem. Rev., 1999, 99, 2293.

3 (a) Y. Lvovsky, E. W. Stautner and T. Zhang, Supercond. Sci. Technol., 2013, 26, 1; (b) T. C. Cosmus and M. Parizh, IEEE Trans. Appl. Supercond., 2011, 21, 2104.

4 (a) P. R. Luijten and D. W. J. Klomp, Drug Discovery Today: Technol., 2011, 8, e103; (b) C. K. Khul, F. Träber and H. H. Schild, Radiology, 2008, 246, 675.

5 (a) L. Helm, Future Med. Chem., 2010, 2, 385; (b) P. Caravan, C. T. Farrara, L. Frullano and U. Ritika, Contrast Media Mol. Imaging, 2009, 4, 89.

6 M. Botta and L. Tei, Eur. J. Inorg. Chem., 2012, 1945.
7 (a) M. R. Longmire, M. Ogawa, P. L. Choyke and $\mathrm{H}$. Kobayashi, Wiley Interdiscip. Rev.: Nanomed. Nanobiotechnol., 2014, 6, 155; (b) A. Bumb, M. W. Brechbiel and P. Choyke, Acta Radiol., 2010, 51, 751.

8 P. Caravan, Acc. Chem. Res., 2009, 42, 851.

9 J. Martinelli, M. Fekete, L. Tei and M. Botta, Chem. Commun., 2011, 47, 3144.

10 (a) W. J. M. Mulder, G. J. Strijkers, G. A. F. Van Tilborg, D. P. Cormode, Z. A. Fayad and K. Nicolay, Acc. Chem. Res., 2009, 42, 904; (b) E. Terreno, D. Delli Castelli, C. Cabella, W. Dastrù, A. Sanino, J. Stancanello, L. Tei and S. Aime, Chem. Biodiversity, 2008, 5, 1901.

11 (a) Y. Song, E. K. Kohlmeir and T. J. Meade, J. Am. Chem. Soc., 2008, 130, 6662; (b) J. B. Livramento, E. Toth, A. Sour, A. Borel, A. E. Merbach and R. Ruloff, Angew. Chem., Int. Ed. Engl., 2005, 44, 1480.

12 (a) D. A. Fulton, E. Elemento, S. Aime, L. Chaabane, M. Botta and D. Parker, Chem. Commun., 2006, 1064; (b) D. A. Fulton, M. O'Halloran, D. Parker, K. Senanayake, M. Botta and S. Aime, Chem. Commun., 2005, 474.

13 (a) L. Van Der Elst, Y. Raynal, M. Port, P. Tisnes and R. N. Muller, Eur. J. Inorg. Chem., 2005, 6, 1142; (b) M. Port, C. Corot, O. Rousseaux, I. Raynal, L. Devoldere, J. M. Idée and A. Dencausse, Magn. Reson. Mater. Phys., Biol. Med., 2001, 12, 121; (c) M. Port, D. Meyer, B. Bonnemain, C. Corot, M. Schaefer, O. Rousseaux, C. Simonot, P. Bourrinet, S. Benderbous, A. Dencausse and L. Devoldere, Magn. Reson. Mater. Phys., Biol. Med., 1999, 8, 172.

14 J. Kotek, P. Lebduskova, P. Hermann, L. Vander Elst, R. N. Muller, C. F. G. C. Geraldes, T. Maschmeyer, I. Lukes and J. A. Peters, Chem.-Eur. J., 2003, 9, 5899.

15 M. Botta, Eur. J. Inorg. Chem., 2000, 399.

16 (a) P. Baia, J. P. Andre, C. F. G. C. Geraldes, J. A. Martins, A. E. Merbach and E. Toth, Eur. J. Inorg. Chem., 2005, 2110; (b) J. P. Andre, C. F. G. C. Geraldes, J. A. Martins, A. E. Merbach, M. I. M. Prata, A. C. Santos, J. J. P. de Lima and E. Toth, Chem.-Eur. J., 2004, 10, 5804; (c) K. Luo, G. Liu, X. Zhang, W. She, B. He, Y. Nie, L. Li, Y. Wu, Z. Zhang, Q. Gong, F. Gao, B. Song, H. Ai and Z. Gu, Macromol. Biosci., 2009, 9, 1227.

17 V. C. Pierre, M. Botta and K. N. Raymond, J. Am. Chem. Soc., 2005, 127, 504.

18 (a) G. Yu, M. Yamashita, K. Aoshima, M. Takahashi, T. Oshikawa, H. Takayanagi, S. Laurent, C. Burtea, L. Vander Elst and R. N. Muller, Bioorg. Med. Chem. Lett., 2007, 17, 2246; (b) M. Takahashi, Y. Hara, K. Aoshima, H. Kurihara, T. Oshikawa and M. Yamashita, Tetrahedron Lett., 2000, 41, 8485.

19 L. Lattuada, A. Barge, G. Cravotto, G. B. Giovenzana and L. Tei, Chem. Soc. Rev., 2011, 40, 3019.

20 J. F. W. Keana and J. S. Mann, J. Org. Chem., 1990, 55, 2868. 21 (a) C. F. G. C. Geraldes, A. M. Urbano, M. C. Alpoim, A. D. Sherry, K.-T. Kuan, R. Rajagopalan, F. Maton and R. N. Muller, Magn. Reson. Imaging, 1995, 13, 401; (b) W. C. Eckelman, S. M. Karesh and R. C. Reba, J. Pharm. Sci., 1975, 64, 704. 
22 (a) S. Dutta, P. Biswas, U. Florke and K. Nag, Inorg. Chem. Commun., 2010, 13, 1074; (b) W. Hayes, H. M. I. Osborn, S. D. Osborne, R. A. Rastall and B. Romagnoli, Tetrahedron, 2003, 59, 7983; (c) A. McAuley, S. Subramanian and T. W. Whitcombe, Can. J. Chem., 1989, 67, 1650.

23 M. A. Williams and H. Rapoport, J. Org. Chem., 1993, 58, 1151.

24 P. L. Anelli, F. Fedeli, O. Gazzotti, L. Lattuada, G. Lux and F. Rebasti, Bioconjugate Chem., 1999, 10, 137.

25 A. Barge, G. Cravotto, E. Gianolio and F. Fedeli, Contrast Media Mol. Imaging, 2006, 1, 184.
26 (a) S. Laurent, L. Vander Elst, F. Botteman and R. N. Muller, Eur. J. Inorg. Chem., 2008, 4369; (b) E. Toth, F. Connac, L. Helm, K. Adzamli and A. E. Merbach, Eur. J. Inorg. Chem., 1998, 2017.

27 S. Aime, M. Botta, F. Fedeli, E. Gianolio, E. Terreno and P. Anelli, Chem.-Eur. J., 2001, 7, 5261.

28 (a) J. R. Cox Jr and M. G. Newton, J. Org. Chem., 1969, 34, 2600; (b) H. C. Manning, M. Bai, B. M. Anderson, R. Lisiak, L. E. Samuelson and D. J. Bornhop, Tetrahedron Lett., 2005, 46, 4707.

29 M. Yar, E. M. McGarrigle and V. K. Aggarwal, Angew. Chem., Int. Ed., 2008, 47, 3784. 